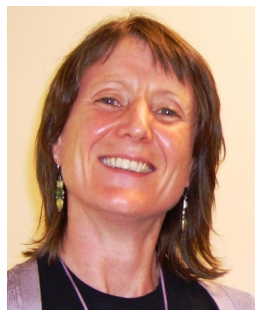

\title{
THE REGULATION OF DIFFUSE POLLUTION IN THE EUROPEAN UNION: SCIENCE, GOVERNANCE AND WATER RESOURCES MANAGEMENT
}

\author{
Sarah Hendry \\ Lecturer in Law \\ IHP-HELP Centre for Water Law, Policy and Science \\ University of Dundee, Scotland, UK
}

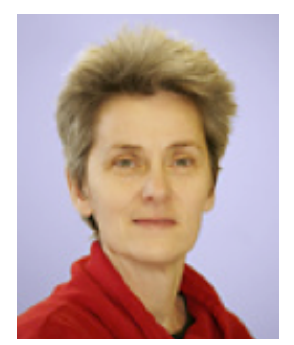

\author{
Alison D. Reeves \\ Reader in Geography \\ School of the Environment \\ University of Dundee, Scotland, UK
}

\begin{abstract}
Reducing diffuse pollution is a perpetuating problem for environmental regulators. This paper will consider novel ways to regulate its impacts on the aquatic environment, with particular reference to rural landuse. It will look at the relationship between science, policy and law, and the contributions of integrated water resources management and governance at regional, national and river basin scales. Regulatory frameworks for water in the European Union will be explored, along with their implementation nationally in Scotland and at catchment scale in the Tweed river basin. It will conclude that regulation has a role to play, but that it is necessary to take a visionary holistic and integrated approach, nesting regulation within a governance framework that involves all stakeholders and takes full account of developing science and socio-economic drivers to meet environmental objectives.
\end{abstract}

\section{The nature of the problem and the role of law}

Diffuse pollution, or non-point source pollution, is increasingly recognised as a problem in all spheres of the environment. In the industrialised nations, the causes and consequences of point source pollution were already being recognised in the $19^{\text {th }}$ century. In the $20^{\text {th }}$ century, much effort was spent on mechanisms to address such pollution, especially through regulation, standards and licensing. It has been much more difficult to find effective solutions to diffuse source pollution and this remains a problem in the $21^{\text {st }}$ century. As with most environmental issues, the problem is multi-dimensional. The nature of the problem, and its consequences for the environment, need some scientific assessment. Ideally, an emerging science consensus will inform emerging policy, which can then be implemented by legal mechanisms to achieve change. But that consensus is not always apparent and the time frames for emerging science research may not fit well with timeframes for developing policy or making law. There are also economic and social imperatives; any solutions must be cost-effective and acceptable to those who must implement them.

There are widely accepted scientific definitions of diffuse pollution as it relates to water:

Pollution arising from land-use activities (urban and rural) that are dispersed across a catchment or subcatchment, and do not arise as a process of industrial effluent, municipal sewage effluent, deep mine or farm effluent discharge. ${ }^{1}$

In practical terms, diffuse pollution is difficult to trace and, therefore, difficult to subject to the types of regulation that would be effective against industrial plant or other fixed sources. Typi-

\footnotetext{
${ }^{1}$ Robert Ferrier et al, 'Diffuse Pollution - What is the Nature of the Problem?' (2005) 19(4) Water and Environment Journal 361.
} 
cal examples are run-off from agricultural activities and urban surface water. The sources, pathways and receptors are all diverse. It is a problem resulting from the multiple activities of individuals and, as such, its management depends, in part, on the willingness (or the capacity) of individuals to change their behaviour.

In the definition given above, 'municipal sewage effluent' is excluded from diffuse pollution. Where domestic and industrial waste-waters are collected and taken to a municipal waste-water treatment plant, the resultant effluent undoubtedly becomes a point source. However, small rural communities are off the sewerage network and often served by septic tanks. While each septic tank is a point source, a proliferation of septic tanks that may be old, badly designed, poorly located or malfunctioning, will cause pollution that is difficult to trace to source. This can also be true of filtration systems, whether used for domestic waste-water, small-scale biodegradable trade waste, farm waste-water, or surface runoff from roads and sealed urban soils. For the purposes of this paper, these are the potential sources of diffuse pollution of interest; the interest is not so much in the type of source but in the nature of the problem. If there are multiple potential sources, if the particular pathway is difficult to trace back and if it is related to the behaviour of individuals - whether as householders or small businesses - then it is a diffuse pollution problem of concern in this paper.

What then is the role of law in managing diffuse pollution? The law may: stipulate design requirements, for example the construction and siting of a septic tank or the design of a crop sprayer; impose product standards such as the types of pesticides on the market; and establish quality (ambient) standards, which measure the quality of receiving waters to assess trends, monitor progress and provide a long-stop for cumulative activities. The law may also establish frameworks for economic tools and incentives, for example through the European Union (EU) system for agricultural support; ${ }^{2}$ and the law can provide procedural mechanisms to enable stakeholder participation in policy developments, whereby those stakeholders have an opportunity to understand the need for changed practices to safeguard the wider environment, to be involved in the design of those new practices or be actively involved in their implementation.

This paper will first examine the legal frameworks relevant to diffuse pollution in the EU and then examine the situation in the Tweed River catchment in Scotland. ${ }^{3}$

In Scotland, where diffuse pollution is a significant problem, there has been a pro-active approach to recent reforms in European water law (especially the EU Water Framework Directive $($ 'WFD' $))^{4}$ and new rules on diffuse pollution that make certain elements, of what would normally be simply regarded as 'good practice', mandatory, with imposition of administrative and, ultimately, criminal sanctions. This action in Scotland is of wider interest, as part of a package of measures to tackle the problem of diffuse pollution in Europe. The focus on Scotland allows examination of how EU law operates in one jurisdiction. The Tweed River basin offers a working catchment scale case study, exploring a nested approach using regulation and governance initiatives to mutually reinforce best practice within a strong legal framework. The paper also describes the findings of a small research project looking at science and governance in a number of sub-catchments on the UK.

\footnotetext{
${ }^{2}$ For general information on the EU Common Agricultural Policy, see <http://ec.europa.eu/agriculture/index_en.htm>.

${ }^{3}$ Scotland is part of the United Kingdom (UK), and the UK is a Member State of the EU. However there is a separate legal system and a devolved Parliament (under the Scotland Act 1998 c46) in Scotland with responsibility for, inter alia, water, the environment and the implementation of relevant EU law. For some discussion of the separate treatment of water in Scots law, both prior to and after devolution, see Sarah Hendry, 'Scotland's Water - Safe Clean Affordable Public' (2003) 43 Natural Resources Journal. Nevertheless the UK state remains the liable entity for any failure in implementation of EU law and the technical standards for the WFD are being developed at the UK level through the UK Technical Advisory Group, see <http://www.wfduk.org/>.

${ }^{4}$ Directive 2000/60/EC of the European Parliament and of the Council of 23 October 2000, Establishing a Framework for Community Action in the Field of Water Policy [2000] OJ L 1/327 ('WFD').
} 


\section{Legal Frameworks in the EU and Scotland}

The WFD was enacted at the regional level in 2000 and establishes a lengthy process for integrated water resource management (IWRM) through river-basin planning. In Scotland, blessed with an abundant water resource, the first set of River Basin Management Plans ${ }^{5}$ produced under the WFD suggest that the two main reasons why rivers will not achieve 'good' quality are morphology and diffuse pollution. ${ }^{6}$

The WFD adopts a 'combined approach', ${ }^{7}$ which is applied to point and diffuse pollution, with 'controls including, as appropriate, best environmental practices' ${ }^{8}$ This is of limited use, but the 'Programme of Measures', part of the detail underpinning the River Basin Management Plans, should include, as a basic - that is, mandatory - measure, the control of diffuse pollution by prohibition or authorisation including general binding rules. ${ }^{9}$ In terms of agricultural use, achievement of best practice in the EU can be significantly influenced by tying in agricultural subsidy to the achievement of good practice (cross-compliance). The EU gives some flexibility to Member States regarding activities that can receive subsidies. Scotland implemented the WFD through the Water Environment and Water Services Act ('WEWS Act') ${ }^{10}$ for river basin planning and, secondary regulation, the Controlled Activities Regulations ('CAR') $)^{11}$ for the management of water uses, including a set of general binding rules.

The river basin planning process itself has relevance to the way that diffuse pollution is managed by noting the importance of engaging those whose activities are the source of the problem. The WFD requires that states or their competent authorities 'encourage the active involvement of all interested parties in the implementation of this Directive', ${ }^{12}$ and also to make available to the general public, within a strict consultative timetable, drafts of various principal documents. ${ }^{13}$ This bare provision within the Directive is supplemented by extensive policy documentation made available through a shared platform for implementation where the development of public participation mechanisms and other implementation tools can be shared between states, authorities and other interested groups. ${ }^{14}$ This leads into a debate which is often expressed in terms of the concept of 'governance', and which will be considered below.

\section{The Regulation of Diffuse Pollution}

The regulation of diffuse pollution must reflect the multi-faceted nature of the problem. Thus, in Scotland, there are specific rules on nitrates, ${ }^{15}$ groundwater, ${ }^{16}$ urban runoff, ${ }^{17}$ agricultural

\footnotetext{
${ }^{5}$ Scottish Government, The River Basin Management Plan for the Solway Tweed River Basin District (2009) <http://www.sepa.org.uk/water/river_basin_planning.aspx>.

${ }^{6}$ Morphological alterations include impoundments and canalisation, often due to the $19^{\text {th }}$ century practice of straightening rivers, which was then considered the best practice mechanism for managing flood risk but has subsequently been found to have negative impacts, especially for salmonid fish. See Christopher Spray et al, 'Bridging the Water Law, Policy, Science Interface: Flood Risk Management in Scotland' (2009) 20 Journal of Water Law 165.

${ }^{7}$ Directive 2000/60/EC of the European Parliament and of the Council of 23 October 2000 Establishing a Framework for Community Action in the Field of Water Policy OJ/L 327/1, art 10.

${ }^{8}$ Ibid $327 / 1$, art $10(2)(\mathrm{c})$.

${ }^{9}$ Ibid 327/1, art 11(3)(h).

${ }^{10}$ Water Environment and Water Services (Scotland) Act 2003 asp. 3 ('WEWS Act').

${ }^{11}$ Water Environment (Controlled Activities) (Scotland) Regulations 2011 SSI 2011/209 ('CAR').

${ }^{12}$ WFD $327 / 1$ art 14.

${ }^{13}$ Specifically, a timetable and work plan, three years before the date of production of any one River Basin Management Plan; an overview of the 'Significant Water Management Issues', two years before production and a draft plan, one year before the final version. In addition the so-called 'Article 5' reports, which provide an economic analysis of water use and an assessment of the pressures and impacts on the resource, will also be made available.

${ }^{14}$ The Common Implementation Strategy is unique to the WFD within the EU; see < http: //ec.europa.eu/environment/ water/water-framework/iep/index_en.htm>.

${ }^{15}$ Directive 1991/676/EEC Concerning the Protection of Waters against Pollution Caused by Nitrates from Agricultural Sources OJ L 375, establishing Nitrate Vulnerable Zones within which member states must establish management plans to control the rate and timing of fertiliser applications; and, in Scotland, the Action Programme for Nitrate Vulnerable Zones (Scotland) Regulations 2008 SSI 2008/298.

${ }^{16}$ Directive 80/68/EEC on the Protection of Groundwater against Pollution caused by Certain Dangerous Substances OJ L $20 / 45$, establishing lists of substances, the discharge of which must be controlled by states, and Directive 2006/118/EC
} 
management, ${ }^{18}$ and flooding, ${ }^{19}$ some stemming from EU law and some purely national. Each of these contribute to managing particular impacts, yet many landuse activities that contribute to diffuse pollution are not encompassed. In spring 2008, the Scottish Government brought forward regulations specifically targeted at diffuse pollution in the rural environment, ${ }^{20}$ subsequently included in the CAR general binding rules. These regulations target specific rural landuse activities, but are not restricted to agriculture or forestry; they also apply to relevant activities on large country estates or golf courses. The final version of the regulations controls seven activities. This paper will consider the three of most general relevance to farming practice: the keeping of livestock, the storage and application of fertiliser and land cultivation. ${ }^{21}$ The specific rules may be of interest from a comparative perspective but this paper will analyse only three aspects: firstly, the legislative and policy-making process and the several draft iterations that were debated and negotiated between 2005 and 2008; secondly, the relationship between the development of that policy into law and the underpinning science; and thirdly, enforcement.

The first step in the legislative process was a general consultation; ${ }^{22}$ each of the subsequent stages involved a set of draft rules, with some significant changes between the second and third consultations. Some prescriptive rules disappeared, especially the all-important minimum distances from watercourses for various activities - distances were reinstated in the fourth and last consultation and the final rules, but with some (not all) of the headline figures reduced. These rules still need to be read alongside the good practice guidance, which encourages more extensive areas of protection than the regulatory distance. ${ }^{23}$

The rules on livestock are targeted at preventing contamination of surface waters or wetlands, and contamination of drinking water sources. This is achieved by distance limits - 'significant erosion or poaching of any land that is within 5 metres of surface water or wetland shall be prevented', ${ }^{24}$ 'livestock shall be prevented from entering any land that is within 5 metres of a spring [or uncapped well] that supplies water for human consumption', ${ }^{25}$ and 'livestock feeders shall not be positioned within 10 metres of any surface water or wetland'. ${ }^{26}$

Similarly, the rules on fertilisers focus on storage and spreading; these, and the rules on land cultivation, establish mandatory distances between these activities and water bodies ('buffer zones' or 'filter strips'). In the final version of the new rules, the original distances for storing

on the Protection of Groundwater against Pollution and Deterioration setting EU-wide quality standards for nitrates and pesticides, and quality standards at state (or river basin) level for substances of concern in that locality.

${ }^{17}$ Especially through the use of sustainable urban drainage systems for surface water management, which can be taken into public ownership if certain design standards are met under the Water Environment and Water Services (Scotland) Act 2003 asp 3 pt 3); also, eg, the requirement to use permeable surfaces instead of hard standing through land use planning, to avoid soil sealing.

18 The Control of Pollution (Silage, Slurry and Agricultural Fuel Oil) (Scotland) Regulations 2003 SSI 2003/531, setting design and product standards for the relevant activities.

${ }^{19}$ The Flood Risk Management (Scotland) Act 2009 asp 6, inter alia, requires mapping of sewer networks and of Sustainable Urban Drainage Systems (SUDS), to address flood risk and consequential diffuse pollution, in both urban and rural contexts.

${ }^{20}$ Water Environment (Diffuse Pollution) (Scotland) Regulations 2008 SSI 2008/54; now incorporated in the Water Environment (Controlled Activities) (Scotland) Regulations 2011 SSI 2011/209.

${ }^{21}$ Other rules include the construction of rural roads and the management of sheep dip. New proposals have recently been made to extend the rules for managing pesticide use, to implement inter alia Directive 2009/128/EC Establishing a Framework for Community Action to Achieve the Sustainable Use of Pesticides OJ L 309/71.

22 Scottish Executive, 'Diffuse Water Pollution from Rural Land Use' (2005) Paper 2005/35 <http://www.scotland.gov.uk/ Publications/2005/12/12152505/25059>; Scottish Executive 'Implementing the Water Environment and Water Services (Scotland) Act 2003: Diffuse Water Pollution from Rural Land Use: Consultation on Proposed Regulations Relating to General Binding Rules' (2006) <http://www.scotland.gov.uk/Publications/2006/10/24155114/0>; Scottish Executive 'Implementing The Water Environment And Water Services (Scotland) Act 2003: Diffuse Water Pollution From Rural Land Use General Binding Rules - A Consultation' (2007) <http://www.scotland.gov.uk/Publications/2007/02/ 06120621/0>; Scottish Executive 'Implementing The Water Environment And Water Services (Scotland) Act 2003: Diffuse Water Pollution From Rural Land Use General Binding Rules And Related Provisions Consultation’ (2007) <http://www.scotland.gov.uk/Publications/2007/09/05093837/0>.

${ }^{23}$ Scottish Government, 'Prevention of Environmental Pollution from Agricultural Activities' (2005) <http://www.scotland.gov.uk/Topics/farmingrural/Agriculture/Environment/PEPFAA/Intro>.

${ }^{24}$ Water Environment (Diffuse Pollution) (Scotland) Regulations 2008 SSI 2008/54, Schedule.

25 Ibid.

26 Ibid. 
fertiliser remain at ten metres from surface waters and wetlands, and 50 metres from wells, springs and boreholes used for human consumption (but there is a new clarification that these do not apply if storage is suitably constructed). Organic fertilisers must not be spread within two meters of drainage ditches, five metres from surface water or wetlands, or 50 metres of consumptive sources; for inorganics, the figures are two metres from surface waters and five meters from consumptive sources. In the second consultation, the distances for application as well as storage were ten metres and 50 metres respectively, which would afford significantly greater protection to aquatic life; but in the third consultation there were no distances for application of fertiliser, only general prescriptions.

In relation to cultivation, we see similar shifts. In the second consultation, distances of two metres and five metres were to be maintained between cultivated land and waterbodies or drinking water sources respectively; but there were much greater prescribed distances for forestry, up to 20 metres depending on the width of the watercourse. In the third consultation there were no specified distances for crops, only a general obligation to take reasonable steps to minimise erosion and avoid pollution; the two metre/five metre distances applied to forestry, depending again on the width of the watercourse. In the fourth consultation, cultivation distances for crops are back at two metres from surface waters and five metres from drinking water sources and this is also the final version; for forestry, a few general provisions in the fourth consultation have now completely disappeared.

The length of this process, and the different thinking reflected in the different versions, shows how difficult it is to legislate for good practice. It is possible to access the responses to the various consultations, which are published, and, perhaps, to match up the concerns of respondents to the next iteration of the rules. What is much less clear in the public process is the way that these rules are underpinned by science.

Unsurprisingly, there is a considerable volume of scientific literature devoted to buffer strips; the results of this literature are not always consistent. ${ }^{27}$ The degree of slope, and the nature of the soil, can both affect the amount of sediment transportation; ${ }^{28}$ and there are always revisions to the science evidence base. ${ }^{29}$ New research may be commissioned prior to developing legislation but at some point there is a need for sufficient certainty to proceed to develop legislation this is an obvious difficulty for policy-makers. Once a rule - or policy position - is established, the science base is still important and relevant for users; thus the environmental regulator in Scotland provides both practical advice and supporting literature on buffer strips as a best management practice. ${ }^{30}$ What is not always evident is how this science is incorporated into the policymaking process. The public consultation responses at each stage - in this as in other aspects of environmental law - tend to come from a few key groups. Water users, fishers, farmers, landowners and managers will respond, sometimes individually and, often, through representative groups. Regulators and authorities will respond, as will environmental organisations and sometimes academics - but not usually those academics from the scientific community. Scientific experts may sit on advisory groups, or give advice to Parliament, but they do not tend to engage with the public consultation process; and nor does the Government tend to allude in any detail to the science when proposing or refining a policy position to the public. For other stakeholders within the process, it appears as if the various policy options exist in a vacuum or are influenced only by social or economic factors relevant to the interested parties; the role of science and scientists is invisible and this may increase the potential difficulties around enforcement.

\footnotetext{
${ }^{27}$ See, for example, the variable distances indicated in Karl Czymmek et al, 'The New York Phosphorous Run-Off Index: Users Manual and Documentation’ CSS Extension Publication E03-13 (2003) Box 3, 15, Cornell University.

28 Soil \& Water Conservation Society of Metro Halifax 'Buffer Strips: Two Suggestions' (2002) <http://www.chebucto.ns.ca/ccn/info/Science/SWCS//////WAB/2002/wab02-08.pdf>.

${ }^{29}$ Gert Verstraeten et al, 'The Use Of Riparian Vegetated Filter Strips To Reduce River Sediment Loads: An Overestimated Control Measure?’ (2006) 20 Hydrological Processes 4259.

30 SEPA (undated) Advice on BMP 79 Riparian Buffer Strips <http://apps.sepa.org.uk/bmp/ShowPractice.aspx?bmp Number $=79>$.
} 


\section{Enforcement}

The enforcement of environmental law is a continuous problem - compounded in the case of diffuse pollution. In Scotland, the Scottish Environment Protection Agency (SEPA) is the 'competent authority' for the implementation of the WFD and other EU environmental laws. For the WFD there are also other 'responsible authorities' with both general duties and specific functions. ${ }^{31}$ Under national law, SEPA has extensive powers to enforce environmental regulation under the Environment Act $1995^{32}$ and, for water, under the CAR. ${ }^{33}$ These include the power to enter premises, take samples, obtain data, question persons and report to the public prosecutor. There is also a power to move up through the tiers of control; although an activity is covered by a general rule or a simple registration, it would be possible to treat a particular instance as requiring registration or a full licence respectively. ${ }^{34}$ The CAR are backed by penal sanction as well as certain administrative sanctions, including the potential revocation of any authorisation.

The CAR offences ${ }^{35}$ include failure to comply with a general binding rule, and also failure to comply with regulation 4 . The latter provides that '[n]o person shall carry on, or cause or permit others to carry on, any controlled activity' which is not authorised. Thus the offence includes both passive and active failures and covers both the actor and anyone having control over that actor, and the maximum fine on summary charge is $£ 40000$, considerably higher than the 15000 maximum usually payable for this level of criminal offence. However most convictions do not result in fines at anything close to that level, ${ }^{36}$ and the public prosecutor may not always agree to a prosecution even where SEPA officers are keen that this should happen. While the size of the jurisdiction and the number of cases each year are unlikely to justify a specialist court or tribunal in Scotland, ${ }^{37}$ in recent years specialist prosecutors have been trained to address the difficulties arising from the complexity of environmental law. New reforms are now being proposed to improve the tools available to the regulators, including fixed penalties and new forms of notices, and these may, in future, increase the options for managing breaches of the general binding rules, but their enactment is not yet certain.

The CAR also provides for statutory defences where the contravention results from an accident, or 'natural causes or force majeure which are exceptional and could not reasonably have been foreseen', and where all practicable steps have been taken to prevent deterioration, to restore the water environment and where SEPA has been notified as soon as practicable. ${ }^{38}$ It is a moot point as to whether, for example, flooding would be considered either unforeseen or exceptional if it subsequently caused or contributed to a pollution incident - as flooding is very likely to do. Historically, the Scottish courts have held that extreme rainfall is an expected event, not an Act of God, so the builder of a dam would be liable in the event of it failing due to heavy rain. ${ }^{39}$ These cases were civil liability actions and the concept has not been tested in the context of modern environmental law. In the event of pollution being caused by ongoing land management activities, which might include efforts to manage flooding, if the courts took a similar approach then criminal or civil liability remains a possibility, albeit unlikely.

\footnotetext{
${ }^{31}$ See Water Environment and Water Services (Scotland) Act 2003 asp 3 s 2; and Water Environment (Designation of Relevant Enactments and Responsible Authorities) (Scotland) Order 2008 SSI 2008/263.

${ }^{32}$ Environment Act 1995 (UK) c 25 s 108.

${ }^{33}$ CAR SSI 2011/209 regs 31-35 and sch 6.

${ }^{34}$ Ibid reg 10.

${ }^{35}$ Ibid reg 44

${ }^{36}$ More serious incidents and those involving larger companies may attract fines in the thousands of pounds, but for less serious incidents, often involving individuals or sole traders, fines may only be in the hundreds of pounds. Imprisonment is rare. Most such cases are not reported, but see for examples 'SEPA View', which includes court updates, avail able at <http://www.sepa.org.uk/about_us/publications/sepa_view.aspx>.

${ }^{37}$ In 2009/10 there were 33 referrals to the prosecutor and 34 convictions secured (noting that convictions may relate to referrals from a previous year); see Scottish Environment Protection Agency 'Annual Report 2009/10', 33 <http://www.sepa.org.uk/about_us/publications/annual_reports.aspx>. Although the 2010/11 report is now available, SEPA is no longer publishing these statistics.

${ }^{38}$ CAR reg 48.

${ }^{39}$ See, eg, Kerr v Earl of Orkney (1857) 20D 298.
} 
In the most recent version of the $C A R$, new defences have been created applicable to 'reasonably necessary' steps taken in the management of emergencies ${ }^{40}$ by designated public authorities. The 'emergencies' and the authorities are defined in separate UK-wide legislation. ${ }^{41}$ Emergencies include 'serious harm to the environment', which in turn includes contamination of water. Authorities include police and fire services, SEPA and water services providers. ${ }^{42}$ Hence if public authorities take 'reasonably necessary steps' to deal with an emergency, which could include flooding, and pollution or other harm is caused, the new defence could be applicable.

Criminal enforcement powers will always be limited by resources and by social acceptability, especially where the source of the problem is the behaviour of many different individuals. A recent survey of Scottish farmers' perceptions of the Nitrates Regulations indicated that many did not accept the basic premise that farming practice is responsible for much nitrate pollution; ${ }^{43}$ the importance of some consensus around the 'science base' for new regulation is relevant here. As part of an ongoing process to address the problem, the Scottish Government proposed the establishment of a Diffuse Pollution Management Advisory Group, ${ }^{44}$ which is now operational. A rolling action plan ${ }^{45}$ includes the enforcement of the diffuse pollution regulations with a focus on certain 'priority catchments', which are failing to achieve good water quality. One mechanism used under the plan is 'farmland walks', whereby officers from SEPA walk the catchment with farmers, identifying specific problems and noting potential contraventions of regulations or breach of good practice guidelines. Then, ideally, information will cascade through the local farming communities as to both the problems and the potential for sanction.

This approach has now been put into practice in the priority catchments, whereby SEPA officers have sent out 3000 leaflets and letters, and walked $2341 \mathrm{~km}$ of riverbank, looking for diffuse pollution breaches and other water quality pressures. This process identified 2355 breaches, mostly relating to livestock, cultivation or fertiliser use. In addition there have been a series of on-farm workshops, focus groups and other outreach activities, as the regulator seeks to take a partnership or compliance approach. The hope is that knowledge of the law and understanding of good practice will disseminate across the farming community.

Such an approach might be effective if the problem is lack of knowledge of the rules. However, it does depend on a high level of regulatory resource - particularly problematic in the current financial environment - and it assumes that, once aware of the problem, rural land managers will appreciate its seriousness and the need for control measures. This, in turn, implies their acceptance of the science base underlying both the problem and the solution. Sanctions alone will not manage diffuse pollution. It requires transparent and participative mechanisms for information flow - vertically and horizontally - between policy makers, various professionals, water users and land managers. It also requires good governance and, perhaps, procedural standards to activate the same. The next section will explore the role of governance and the legal and social processes that can increase stakeholder involvement in problem solving.

\footnotetext{
${ }^{40}$ CAR reg 48(a)(iii).

${ }^{41}$ Civil Contingencies Act 2004 (UK) c 36

${ }^{42}$ Ibid s 19 and sch 1.

${ }^{43}$ Andrew Barnes et al, Implementing the Action Programme for Nitrate Vulnerable Zones in Scotland: Farming Practices and Awareness (2008) Scottish Government Publication <http://www.scotland.gov.uk/Publications/2008/01/ 07105336/0>.

${ }^{44}$ The Diffuse Pollution Management Advisory Group is constituted as an Advisory Group under the Water Environment and Water Services (Scotland) Act 2003 asp 3 s17.

${ }^{45}$ DPMAG Rural Diffuse Pollution Plan for Scotland <http://www.sepa.org.uk/water/river_basin_planning/diffuse pollution_mag.aspx>.
} 


\section{Governance and Stakeholder Engagement}

'Governance' is currently a popular concept with academics and policymakers, not just in relation to water resources ${ }^{46}$ and water services ${ }^{47}$ but also in a wide variety of political contexts. Governance has been defined as:

[The] exercise of economic, political and administrative authority to manage a country's affairs at all levels ... the mechanisms, processes and institutions through which citizens and groups articulate their interests, exercise their legal rights, meet their obligations and mediate their differences'. ${ }^{48}$

Subsequently, 'water governance' has been defined as:

[The] range of political, social, economic and administrative systems that are in place to develop and manage water resources, and the delivery of water services, at different levels of society'. ${ }^{49}$

From a legal perspective, governance can be assessed by looking at the (related) objectives of accountability, transparency and participation, ${ }^{50}$ and then by introducing specific legal procedures designed to mandate engagement with stakeholders.

\section{Governance and Water Resources Management}

The popularity of the governance concept should not blind us to its potential flaws, especially its 'catch all' nature whereby it can mean everything and nothing. Nonetheless it can usefully encapsulate some important ideas about the management of water and is closely aligned to the concept of integrated water resource management (IWRM).$^{51}$ IWRM takes into account the coherence and integrity of hydrological (river basin) boundaries rather than pre-existing administrative structures and recognises the interdependence of the water cycle, especially the integrated management of surface and groundwater. It also involves engagement with relevant stakeholders to ensure both coordination and equity.

IWRM has been a policy goal at the international level at least since 1992 and finds expression in 'Agenda $21^{, 52}$ and in the Johannesburg Declaration and Plan of Implementation. ${ }^{53}$ Most commentators accept the desirability of an integrated approach to managing water and some would argue that IWRM has attained the status of a legal norm. ${ }^{54}$ It is being implemented in many parts of the world; the WFD is only one - albeit a comprehensive and sophisticated - example of a legislative framework.

For the purposes of this paper, IWRM and river basin management are interchangeable. Both management processes require mapping and assessing the water environment. Very often they also require the production of a plan or strategy, setting targets and goals, and making explicit the necessary trade-offs between economic, social and environmental needs. The involvement of different groups of stakeholders, water managers and water users is also required. The next sec-

\footnotetext{
${ }^{46}$ Peter Rogers and Alan Hall, 'Effective Water Governance' (2003) Global Water Partnership TEC Paper 7.

${ }^{47}$ Miguel Solanes and Andrei Jouravlev, 'Water Governance for Development and Sustainability' (2006) UN CEPAL.

${ }^{48}$ United Nations Development Programme 'Governance for Sustainable Human Development' (1997) UNPD Publication s 1 <http://mirror.undp.org/magnet/policy/chapter1.htm>.

${ }^{49}$ Rogers and Hall, above n 46, 7.

${ }^{50}$ Alistair Rieu-Clarke and Andrew Allan, 'Role Of Water Law: Assessing Governance In The Context Of IWRM - An Analysis Of Commitment and Implementation in The Tagus and Sesan River Basins' (2008) EU STRIVER Project Report No D6.3 t <http://kvina.niva.no/striver/Disseminationofresults/tabid/70/Default.aspx>.

${ }^{51}$ See Global Water Partnership Technical Advisory Committee 'Integrated Water Resources Management' (2000) TAC Background Paper No 4 <http:/ / www.gwpforum.org/servlet/PSP?iNodelD=215\&itemld=24>.

52 United Nations 'Agenda 21: An Agenda For The 21st Century’ A/CONF 152/126 (1992) para18.3 ('Agenda 21') <http://www.un.org/esa/sustdev/documents/agenda21/english/agenda21 toc.htm\#sec2>.

${ }^{53}$ Report of the World Summit on Sustainable Development, UN Doc A/CONF/199/20 (2002) incorporating Johannesburg Declaration and Plan of Implementation, para 26.

${ }^{54}$ See Salman Salman and Daniel Bradlow, Regulatory Frameworks for Water Resources Management (World Bank Washington DC, 2006) ch 2, s 3.2.
} 
tion will look at the management used structures to achieve this involvement in the EU and in the Scottish case study.

\section{Formal Mechanisms for Stakeholder Engagement}

The provision for public participation by WFD appears minimal, but there is in fact extensive guidance, a strict timetable for the publication of key documents for comment and a requirement to provide all background documentation upon request. Governments and basin authorities should consider input by the public when developing the plans.

In Scotland, there are only two river basin districts (RBD): the Scotland RBD, which includes central and northern Scotland and the outlying islands; and the Solway-Tweed RBD, which runs across southern Scotland and into northern England. There are eight 'sub-basins' within the Scotland RBD and two within the Solway-Tweed - the Solway and the Tweed. ${ }^{55}$ The WEWS Act establishes the river basin planning process and SEPA, a non-departmental public agency, has considconsiderable control over this process. The WEWS Act specifies certain groups of stakeholders who should be given the opportunity to participate, including local authorities, Scottish Natural Heritage (the conservation agency), Scottish Water (the public water services supplier), representatives of business and of environmental interests, and 'such other persons as SEPA may see fit'. ${ }^{56}$ Individual landowners will be represented through, for example, the National Farmers' Union, the Scottish Landowners' Federation or the Scottish Rural Property and Business Federation all are powerful lobby groups. The WFD timetables for publication of key documents are set out in national law and these must be made available for anyone to comment. ${ }^{57}$ All of this creates strong process obligations that entitle participation at least for the identified groups, and mandate an inclusive and responsive authority. The draft river basin management plans were published in December $2008^{58}$ and, when the final versions were produced in December 2009, ${ }^{59}$ one of the accompanying documents was a statement as to how SEPA had responded to the comments received on the draft. ${ }^{60}$ This requirement for decision-makers to explain how they addressed stakeholder inputs to the decision-making process is an important procedural standard in implementing the concept of governance - addressing as it does all three key goals of transparency, participation and accountability.

The WEWS Act also specifies the creation of Advisory Groups. ${ }^{61}$ Each of the ten sub-basins in the two RBDs has an area advisory group (AAG), ${ }^{62}$ as well as a wider area advisory group forum for members of the public or smaller groups that are not represented within the AAGs. ${ }^{63}$ The AAGs work along with the national stakeholder forum that advises the Government on WFD issues; ${ }^{64}$ the scientific community is likely to be represented at both national and area scale. In spite of the required levels of representation, these mechanisms may still be perceived as top-down Government or of not reflecting the real needs of water users. To affect the behaviour of individuals on the ground, another nested layer of governance is required: at catchment scale.

\footnotetext{
${ }^{55}$ The WFD provides for optional 'sub-basin plans', Directive 2000/60/EC of the European Parliament and of the Council of 23 October 2000 Establishing a Framework for Community Action in the Field of Water Policy 0J L 327/1 art 13(5); 'sub-basins' may be individual hydrological units (catchments, river basins, watersheds) that are combined into administrative 'river basin districts' for planning purposes. Going beyond the WFD requirements, sub-basin plans are mandatory in Scotland; Water Environment and Water Services Act 2003 (Scot) asp 3 s 15.

${ }^{56}$ Ibid s $11(6)$.

57 Ibid s 11(1)-(3).

${ }^{58}$ Draft RBMPs for the Scotland and Solway Tweed RBDs, and all prior and accompanying documents, are available at <http://www.sepa.org.uk/water/river_basin_planning/early_basin_planning_work.aspx>.

59 Scottish Government 2009 River Basin Management Plans above n 5.

${ }^{60}$ Scottish Environment Protection Agency 'The River Basin Management Plan for the Scotland River Basin District: Summary of Responses to the Draft Plan Consultation'; 'The River Basin Management Plan for the Solway Tweed River Basin District: Summary of Responses to the Draft Plan Consultation’ (2009) <http://www.sepa.org.uk/water/river_basin_ planning/early_basin_planning_work.aspx>.

${ }^{61}$ Water Environment and Water Services Act 2003 (Scot) asp 3 s 17

${ }^{62}$ See <http://www.sepa.org.uk/water/river_basin_planning/area_advisory_groups.aspx>.

${ }^{63}$ See <http://www.sepa.org.uk/water/river_basin_planning/area_advisory_groups/area_advisory_group_forums.aspx>.

${ }^{64}$ See <http: / / www.scotland.gov.uk/Topics/Environment/Water/WFD/WhoDoesWhat/NationalStakeholderForum>.
} 


\section{Water Governance in the Tweed Basin and the Role of the Tweed Fo- rum}

The Tweed catchment is predominantly rural, with 75 per cent of land used for agriculture and much of the rest for forestry. The Forestry Commission is a key player, both as policy-maker and as landowner. Textiles, once a major industry, have made some recovery here, and tourism is important. The principal local authority is the Scottish Borders Council, but its area extends a little further west into Scotland and does not include the English portion; the classic dichotomy between administrative and hydrological boundaries.

The Tweed is a major salmon river, with 15 per cent of the UK's spawning grounds for Atlantic salmon; landowners with salmon fisheries are powerful stakeholders. Waters in the basin are 'salmonid waters', to which special protection applies: SEPA may restrict river works in order to protect spawning grounds and nurseries. There are extensive protected conservation sites. Thus the Tweed provides ecosystem services of considerable environmental, social and economic benefit, with a high dependency on private landowners to cooperate with the policy-makers and regulators in the management of all elements of the natural environment.

In Scotland, prior to the WFD, there was no statutory provision for river basin management, but there were and are a number of catchment management activities and organisations, which may have functioning catchment plans and are now likely to be playing a lead role in the Area Advisory Groups. One such organisation is the Tweed Forum, ${ }^{65}$ which had already produced a Catchment Management Plan for the basin ${ }^{66}$ and is now a major player in the Area Advisory Group. The Tweed Forum brings together many different stakeholder groups in the public and private sectors and has been working with their partners since 1991. Its objective is 'to promote the sustainable use of the whole of the Tweed catchment through holistic and integrated management and planning', ${ }^{67}$ and it does not refer (only) to water; it is landuse patterns that affect water manage-

ment. Currently the Forum has 25 members, which include the statutory agencies, the regulators, the local authorities, central government as well as environmental NGOs and local business interests. ${ }^{68}$ Thus there is considerable crossover with the groups that must be given opportunities to participate in the statutory process. ${ }^{69}$ In addition, the Forum facilitates the AAG and effectively has a formal role in implementation of the statutory process. Although other catchment groups in Scotland have a similar good relationship with formal river basin planning, ${ }^{70}$ none have quite the status of the Tweed Forum.

Furthermore, the Forum can facilitate links and activities for other purposes. The Tweed river basin is a 'HELP' basin, designated under UNESCO's Hydrology, Environment, Life and Policy programme. ${ }^{71}$ HELP is designed to address barriers to communication in water management in various ways. These barriers exist both horizontally (between the various water professionals and academics) and vertically (between policy-makers and professionals and between the professionals and water users). Water users, whether from developed or developing countries, who do not have specialist skills and the technical language may find it difficult to understand and work with professionals and water managers; organisations such as the Forum are one mechanism to bridge the gap between different groups.

\footnotetext{
${ }^{65}$ See Tweed Forum <http://www.tweedforum.com/>.

${ }^{66}$ Tweed Forum, Tweed Catchment Management Plan (2010) <http://www.tweedforum.com/cmp>.

${ }^{67}$ Above $\mathrm{n} 65$.

${ }^{68}$ See <http://www.tweedforum.com/ourwork/obj2249>.

${ }^{69}$ For the minutes, meetings and membership of the Tweed AAG see <http://www.sepa.org.uk/water/river_basin planning/area_advisory_groups/tweed.aspx>.

${ }_{71}^{7}$ See, eg, The Dee Catchment Partnership <http://www.theriverdee.org/>.

${ }^{71}$ For information on the UNESCO IHP-HELP Programme see <http://www.unesco.org/new/en/natural-sciences/ environment/water/ihp/ihp-programmes/help/>.
} 


\section{Science, Governance and Behavioural Change}

A recent small research project, funded by the Carnegie Trust and carried out by the IHP-HELP Centre for Water Law, Policy and Science at the University of Dundee, in Scotland, involved visiting several river basins throughout the UK, all of which, like the Tweed basin, are members of the UNESCO IHP-HELP programme. The purpose of the project was to study the implementation of the WFD and its links to catchment management 'on the ground', in basins with experience of both long-term science projects and related stakeholder initiatives. ${ }^{72}$ These projects were likely to influence policy-making for water and land use and, ideally - through working with stakeholders - should support positive changes in behaviour. Diffuse pollution was a major problem in almost all of these catchments and a focus for many of the research projects.

In each of the basins visited, the researchers found that these projects offered opportunities, not just to instrument basins for data collection, but also to form working relationships with other organisations and institutions in the public, private and voluntary sectors and, crucially, to form relationships with local communities, residents and landowners including farmers. In these social networks, a number of consistent themes emerged. The longer the term of the projects, the better the linkages formed. Over time, it was possible to gain positive responses from both communities and individuals. Where there was a particular water management problem, people were much more receptive to initiatives such as community meetings, which required them to give up some time. In many situations, the science teams were seen as relatively neutral and a source of less biased and more reliable information than a government agency, ${ }^{73}$ but the scientists needed to be mindful of the technical nature of the information they provided and the need to use accessible language. Many people were keen to have information, for example, on the functioning of their septic tanks $;^{74}$ as noted above, these are a significant contributor to base levels of nutrient pollution. ${ }^{75}$ There were always some people - regardless of the evidence or arguments, and sometimes even despite the availability of financial inducement - who did not wish to change behaviour; ${ }^{76}$ yet other landowners were very receptive to being actively involved in projects to improve the scientific evidence on which policy-into-law is based. These findings reinforce lessons learned on the Tweed. Importantly for the future of catchment-based initiatives such as the Tweed Forum or the HELP programme, where good relationships are established, these can outlast the specific projects for which funding was initially obtained.

The more complex the scientific problem, and the more disputed the evidence, the more difficult it will be to gain consensus and change behaviour. The conclusions to this article posit that the only way to address diffuse pollution - and by analogy other aspects of individual behaviour impacting on the environment - is by a combination of encouragement, education and regulation that could be summarised within the concept of governance, operating at the appropriate scale. The WFD itself sets out a high level IWRM framework at regional scale. The Scottish diffuse pollution regulations are an example of specific rules at the national level, working with other specific regulations and general provisions for enforcement and sanction; but to persuade individuals to buy into change, local networks are required. The relationship between scientists and policymakers may not be obvious in a public process at national scale - but where work is underway at a local scale, within a governance agenda, communication can take place around the science and its relationship to policy and to law. Thus good governance works to improve information flows

\footnotetext{
72 Sarah Hendry and Michael Bonell, 'Developing Networks Amongst UK River Basins: Interfacing Science With Emerging Law And Policy Frameworks' (2010) Report, IHP-HELP Centre for Water Law, Policy and Science, University of Dundee.

${ }^{73}$ Sara Davidson et al, psos MORI, 'Scottish Environmental Attitudes and Behaviours Survey 2008' (2009) Scottish Government Publication available at <http://www.scotland.gov.uk/Resource/Doc/263223/0078735.pdf> Nearly half of those surveyed trusted 'independent' scientists, though 'Government scientists' rated only nine per cent, around the same as Governments themselves.

${ }^{74}$ Dr Susan Cooksley, Dee Catchment Partnership, personal comment, Wednesday 23 June 2010.

75 Joerg Arnscheidt et al 'Defining The Sources Of Low-Flow Phosphorus Transfers In Complex Catchments' (2007) 1-13 Science of the Total Environment 382.

${ }^{76}$ Professor Phil Jordan, Agricultural Catchments Programme, Teagasc, personal comment 25 August 2009.
} 
both horizontally between water users and vertically between them and the professionals involved, and increases the likelihood of positive behavioural change.

\section{Conclusions}

This paper has examined the problem of diffuse pollution of watercourses, primarily in rural environments, through the lens of a legislative framework that is established at the regional scale of the EU, but implemented in detail in national and local rules. At a strategic level, the requirement is for a complex structure of IWRM, using river basins as the main planning unit. At operational level, the detailed rules use different types of standards, as well as financial incentives, to manage relevant activities. Standards are enforced through administrative law and ultimately by criminal penalty, but also through education, the provision of information and the encouragement of good practice.

River basin planning should result in the production of a considerable array of water quality data, identifying key sources, pathways and receptors within a basin; for example, by identifying the relative contributions of point and diffuse pollution, the impacts of changing the structure of a river and potential land areas that could be used for natural flood management. This data can help to establish management techniques to address problems upstream, taking a preventative approach. The defining feature of diffuse pollution is that it has multiple sources, which are difficult to trace and therefore difficult to regulate. The favoured approach is good practice guidance, backed by financial incentives where available. In Scotland, a series of rules exist addressing specific sources of diffuse pollution, including new regulations covering a variety of rural landuse activities. These effectively enshrine some good management practices into law, yet enforcement is still a problem. Further, these specific provisions, although interesting for their attempt to enshrine good practice in law, are only a small part of a much bigger picture. It is necessary to take a nested approach to the problem, allowing for specific and general legislation and enforcement mechanisms but within a governance framework. Science inputs are needed for the legal rules, but socio-economic factors are more important to enable effective enforcement and governance (see Figure 1).

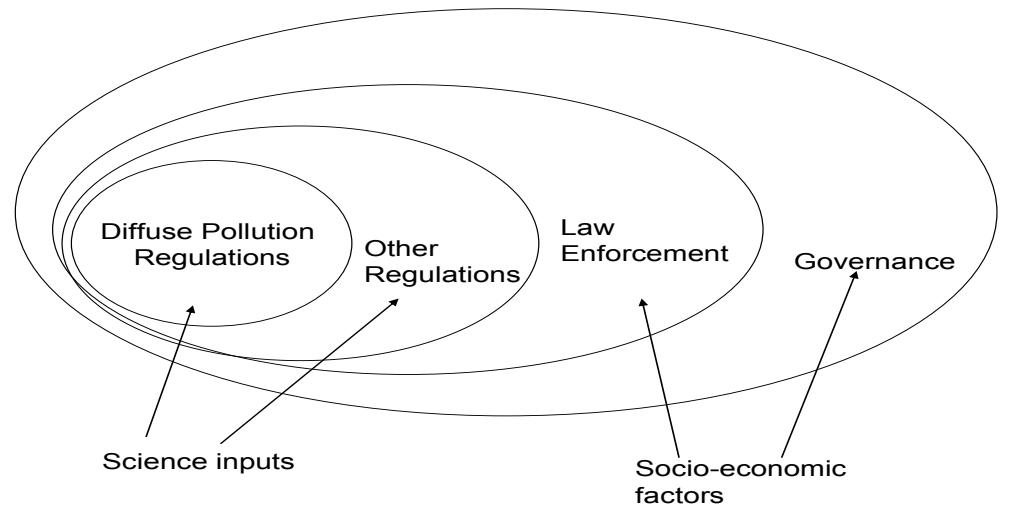

Figure 1: A nested approach.

If one element of IWRM is data collection and forward planning, another is stakeholder engagement. This links to the established concept of sustainable development and the evolving ideas of governance in that both emphasise the participation of users, transparency of decision-making and the accountability of authorities. The WFD sets procedural requirements for consultation and 
data flow and requires a more inclusive decision-making process, at least for key stakeholders. In Scotland this has been achieved, albeit at a high level, for the most significant players in the public and private sectors. The river basin management plans have identified a significant problem with diffuse pollution in rural areas, primarily from nutrients but potentially originating from both farming and waste water. In urban areas, diffuse pollution from surface water is a particular issue; here design solutions are preferred to classical enforcement means, but behavioural change is still relevant. Increased flooding caused by climate change is likely to worsen all of these impacts.

The question remains as to how best to achieve the required shift in attitude and behaviour. This requires, firstly, an understanding of the problem and, therefore, acceptance of the underlying science. An IWRM framework can establish mechanisms and linkages between relevant authorities and users but is often at a high level and risks becoming a top down process. Certainly in Europe, the WFD operates as a regional framework, which then needs implementation at lower scales. At the national level, regulations and standards can be set and can incorporate emerging scientific understanding, but water management inevitably takes place at a local scale and needs to engage local stakeholders. The most effective way to carry the message to water users on the ground is by trusted networks, established over extended periods. The governance frameworks established in the Tweed River Basin through the Tweed Forum enable the formal IWRM processes to reach out to all users, not just the representatives participating in the high level legislative process. These forms of stakeholder engagement allow IWRM to reach its full potential and are the only means by which problems such as diffuse pollution can be effectively addressed in ways that are economically realistic, socially acceptable and environmentally positive. 